\title{
Report row ousts top Indian scientist
}

\section{Ruckus over call for reform at national science agency raises fears for attracting expatriate talent.}

\section{BANGALORE}

The first appointment in a scheme to recruit expatriate scientists to senior positions in the Council of Scientific and Industrial Research (CSIR) - India's largest science agency seems to have misfired badly.

A US scientist of Indian origin has been dismissed just five months after he was offered the position of 'outstanding scientist' and tasked with helping to commercialize technologies developed at CSIR institutes.

Shiva Ayyadurai, an entrepreneur inventor and Fulbright Scholar with four degrees from the Massachusetts Institute of Technology in Cambridge, was the first scientist to be appointed under the CSIR scheme to recruit about 30 scientists and technologists of Indian origin (STIOs) into researcher leadership roles.

"The offer was withdrawn as he did not accept the terms and conditions and demanded unreasonable compensation," Samir Brahmachari, director general of the CSIR, told Nature.

Ayyadurai denies this. In a 30 October letter to Prime Minister Manmohan Singh, who is also president of the CSIR, he claims that he was sacked for sending senior CSIR scientists a report that was critical of the agency's leadership and organization. The report, published on 19 October, was authored by Ayyadurai and colleague Deepak Sardana, who joined the CSIR as a consultant in January. Ayyadurai says that the report - which was not commissioned by the CSIR - was intended to elicit feedback about the institutional barriers to technology commercialization.

"Our interaction with CSIR scientists revealed that they work in a medieval, feudal environment," says Ayyadurai. "Our report said the system required a major overhaul because innovation cannot take place in this environment."

Ayyadurai says that he came to the CSIR with a "mission" to apply his scientific and entrepreneurial experience to help his homeland, and that Brahmachari had promised him the authority, budget and resources to execute the mission. But Ayyadurai's relationship with Brahmachari soured after the report went public. Ayyadurai claims that on 23 October he was barred by the CSIR from speaking to council scientists or directors, and was denied Internet and e-mail access. His appointment offer was

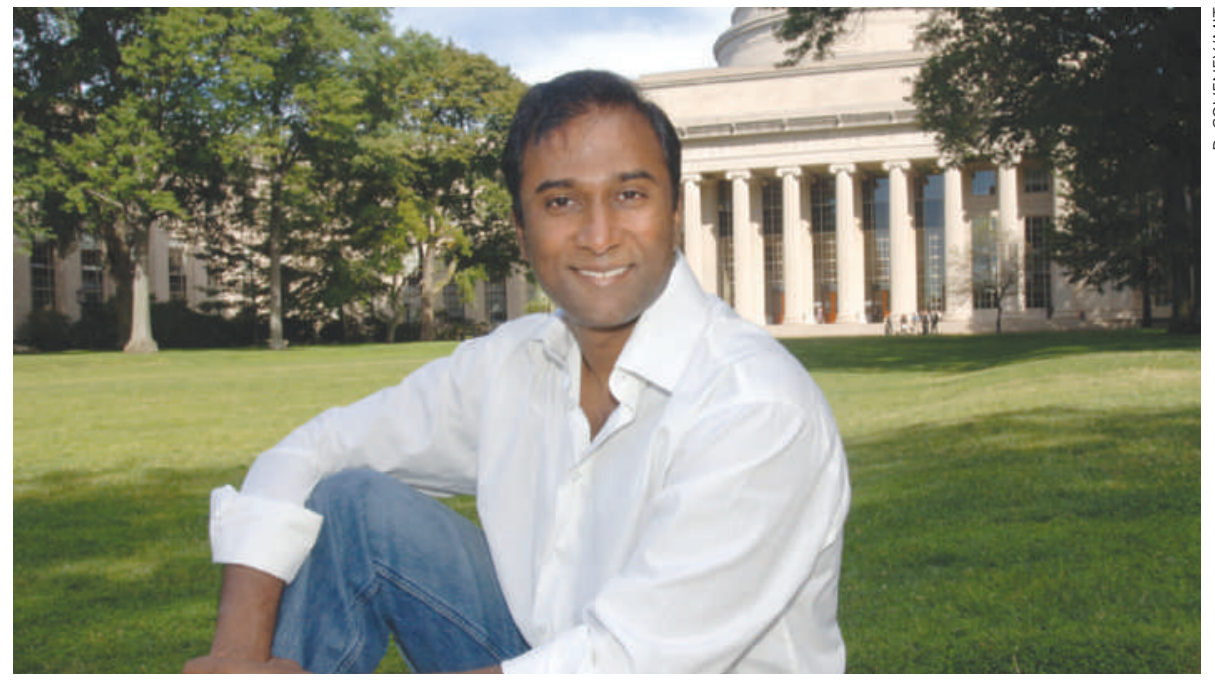

Shiva Ayyadurai says he returned to India on a "mission" to help his homeland.

withdrawn on 26 October, and on 7 November he was given three days to vacate his residential accommodation provided by the CSIR. Brahmachari confirms this chain of events.

Sardana shares Ayyadurai's views. Describing their report as an in-depth study of the management of the CSIR, he wrote to science minister Prithviraj Chavan on 19 October saying that "it is not possible for me to continue working without your immediate direct intervention" because of the problems triggered by the report.

\section{Impervious to criticism}

"I have seen many cases of vindictiveness in the CSIR, but this is the worst," says Pushpa Bhargava, founder director of the CSIR's Hyderabad-based Centre for Cellular and Molecular Biology (CCMB). Bhargava, who has also written to Singh supporting Ayyadurai, says: "Ayyadurai’s report tells the truth about how the CSIR is being run today. The fact that CSIR administration is impervious to healthy and fair criticism is bound to send the wrong message not only to expatriates but also [to scientists] within the country."

"I am more worried that the incident will dampen the enthusiasm of Indian institutions to hire expatriates in the future," says Valangiman Ramamurthy, the former science secretary of the government's Department of
Science and Technology, who recommended Ayyadurai's selection.

But others think that Ayyadurai's case will not set a precedent. Gangan Pratap, director of the National Institute of Science Communication and Information Resources, a CSIR institute in New Delhi, says that most returning expatriates will focus on research and teaching, rather than getting involved with policy issues, and are unlikely to face similar conflicts. Rajan Sankaranarayanan, who returned from the Institute of Genetics and Molecular and Cell Biology in Strasbourg, France, to join the CCMB in 2002, agrees that the episode should not discourage other Indians from returning, as long as they are prepared to work within the existing systems.

Brahmachari is also optimistic. "Serious scientists from top institutions around the world have shown their willingness to join the CSIR's STIO programme, not because of perks or position, but because of the intellectual environment that the CSIR offers," he says. "Right now we have requests from several top people from the United States wanting to work in the CSIR."

\section{K. S. Jayaraman}

\section{Correction}

The European Research Council will appoint

a leading scientist to the new post of director, which is not a direct replacement of the current secretary-general Andreu Mas-Colell as we suggested in our News Briefing item (Nature 461, 1178; 2009). 